\title{
STATUS OF THE SUBJECT PHYSICAL EDUCATION AND SPORT IN THE UNIVERSITIES OF REPUBLIC OF BULGARIA
}

\author{
P. Hristova* \\ Sport Department, University “St. Kliment Ohridski”, Sofia, Bulgaria
}

\begin{abstract}
The immobilization of humanity is a global problem for which warn scientists from around the world. A number of reports of organizations of the world, national and regional levels, state poor health condition of people, and especially of children and youth are due to low physical activity. In response, the relevant Ministries (including the Bulgarian) have drawn up laws and regulations for their implementation. They aim to spread the physical activity among the nations by providing all necessary conditions for sport activities as well as educating people on the importance of regular exercise for the health. Thus, the PURPOSE of this study was to establish the status of the subject Physical Education and Sport in Bulgarian universities' curricula and how the Physical Education and Sport Act is interpreted and applied. The RESULTS show that Bulgarian universities interpret and apply the Low loosely and selectively. CONCLUSIONS are that the State and universities generally do not conduct policy for encouraging students to exercise.
\end{abstract}

Key words: immobilization, universities, students, physical activity, Physical Education and Sport Act, $\mathrm{PE}$ and Sport subject's curricula.

\section{INTRODUCTION}

The development of our civilization has largely altered the way we live by immobilizing us. The hypodynamia, due to the massive influx of modern technologies into our everyday life, has led to the alarming findings of a number of studies on people's health and especially on child and youth age. Back in ancient times, Aristotle have said: "Nothing so wears out and destroys the human organism, as long-term physical inactivity!". Scientists have long established that one of the most risky health determinants is the lack of physical activity. Immobilization causes premature aging, slows the metabolism, thus leading to obesity and the development of various diseases. Because of a sedentary lifestyle, the symptoms of ageing, such as physical infirmity and diminished intellectual capacity, occur much earlier than normal. The lack of physical activity leads to

\footnotetext{
*Correspondence to: Petya Hristova, Sport Department, University "St. Kliment Ohridski", Sofia, Bulgaria, E-mail: pstojanovh@uni-sofia.bg; petya1973@yahoo.com, Mobile: +359878429842
}

the fact that on the age of 12-13 years begins the aging of the respiratory and cardiovascular systems. Because of reduced physical activity, the so-called "hypokinetic disorders" - a complex disorder, including significant negative changes at all levels of the body, occur. Consequences of these disorders are insomnia, lethargy, drowsiness, bad mood, weakening of cognitive abilities, memory and attention, irritability, aggression, decrease of the overall physical abilities (1).

Targeted researches by UNESCO and many scientific institutes have proven that one of the most powerful factors to combat the arising, due to hypodynamia problems, is the influx of wide spreading the physical exercise and sport into people's lifestyle as the main component of the modern model for a healthy life, in the broadest sense of this notion. The World Health Organization (WHO) defines this model as: "A state of complete physical, mental and social well-being, not just a lack of disease". For improving or maintaining good health, it recommends for adults aged 18-64 years, at least 150 minutes of moderate- 
intensity physical activity throughout the week, or at least 75 minutes of vigorous-intensity physical activity throughout the week, or an equivalent combination of moderate- and vigorous-intensity activity. For additional health benefits, adults should increase their moderate-intensity physical activity to 300 minutes per week, or equivalent. Musclestrengthening activities should be done involving major muscle groups on 2 or more days a week (1).

In response to the above-mentioned alarming findings, all existing international, continental, intergovernmental and governmental organizations have long adopted and signed charters and plans for actions related to accustoming the population to regular physical exercises and active lifestyle.

Since its establishment, the European Union also leads an active policy for improving its nations' health through physical activity.

- European Sport for All Charter. Adopted at the Conference of European Sports Ministers, in Brussels in 1975. It proclaims the right of every person to actively engage in sport. The document states that sport is an important factor contributing to and supporting the development of both the individual and the overall advancement of society, which is why the governments must prioritize its financing and create organization and conditions to be embedded in education, health and social services, etc. (2).

- European Sports Charter. Established in 1992 , it is to this day the leading document of the Council of Europe, which gives the legal definition of the concept of sport. According to the document, the Governments of the Member States must stimulate and encourage people for physical exercise and sport activities, ensuring measures for the development of the physical training of people, regardless of the purpose of its practice, as well as the inclusion and availability of Physical Education in different forms in all educational institutions (2).

- Resolution (2007/2086 (INI)) of the European Parliament (13 November 2007) on the role of sport in education. It stresses that the Physical Education and Sport is the only subject that aims to prepare people for a healthy lifestyle and contributes to their complete physical and mental development (3).
HRISTOVA P., et al.

- Resolution (2011/2087 (INI)) of the European Parliament (2 February 2012) on the European dimension in sport. In this document, European Parliament defines sport as an important social phenomenon and national wealth. The Resolution stresses that each Member State must make the necessary efforts to promote the practice of sport activities in schools and universities (4).

- Resolution (2011/C 162/01) of the Council and of the Representatives of the Governments of the Member States, meeting within the Council, on a European Union Work Plan for Sport for 2011-2014. According to it, sport is not only a healthy lifestyle and an elective leisure activity, but also an efficient way and means to increase the working capacity. Recognising and stressing its enormous social role, the document underlines the need of promoting European cooperation in the field of sport as well as drawing a long-term plan, in which sport has its essential mission in the education, training and qualification of people thus strengthening their health. (5)

- White Paper on a Strategy for Europe on Nutrition, Overweight and Obesity related health issues (Brussels, 30.5.2007/COM(2007) 279 final). The document sets out an integrated EU approach to reducing ill health due to poor nutrition, overweight and obesity by promoting healthy diets and physical activity to EU nations. The strategy emphasizes the importance of building up partnerships across the EU to take action on the ground, i.e. at local, regional and national levels, as well as at EU level. These involve the private sector (e.g. food manufacturers, retail and the advertising industry), the public health sector and civil society organizations (e.g. sports, consumer and public health associations) working together. EU countries' authorities are responsible for coordinating to ensure the relevance of the measures in the field of public health (6).

- HEPA Europe (European network for the promotion of health-enhancing physical activity). Created to work for better health and wellbeing in the WHO European Region through more physical activity for all people. Its mission is to provide a forum for the advancement of health-enhancing physical activity (HEPA) research, policy and practice across the WHO European region (7).

All documents highlight the urgent need of educating people on the importance of regular 
HRISTOVA P., et al.

exercise for improving their health and having good quality of life, respectively.

The relevant ministries of EU Member States (including the Bulgarian) have drawn up laws (with focus on children and youth), regulations and plans for their implementation in accordance with EU policy in the field. Accordingly, the main strategic objective of the Bulgarian policy is the promotion of physical education, sport and social tourism as a means to improve the health and physical fitness of the population and maximizing the share of the organized sport activities for all social groups, as well as raising the nation's sport prestige at a global level. The realization of the main strategic objective and activities of the system should be organically bounded with the programs for cultural, educational, social and health development of the nation (8).

The lack of physical activity and the obesity in childhood and adolescent are prerequisites for the emergence of health problems at a later period of life. Therefore, the need for physical activity is much greater in children and adolescents (9). According to the Bulgarian Ministry of Youth and Sport, the tendency for the ever-growing immobilization of the rising generation is unfavorable $-51.0 \%$ of the total adolescents are highly immobilized. The level of their physical development and fitness, compared to previous generations of their peers, is significantly reduced (8). The health and vitality of the nation are extremely important to any society. The theory and methodology of Physical Education clearly says that teaching to regular exercises should start at the earliest childhood, so that the sport and active lifestyle can subsequently become a need. Due to a number of well-known problems in the system of Physical Education in Bulgaria, in recent years there have been a tendency ever-increasing percentage of the newly admitted university students to have an ever-lower physical activity and low motivation for active exercise and sport activities. This is why preserving and/or improving their health and creating knowledge, skills and habits in students for a healthy lifestyle, is one of the main tasks in front of the sports professors at the Bulgarian universities. High education is the final stage of the education system and, accordingly, the last chance to perform this important task.
In response to the above-mentioned worrying fact and in accordance with EU recommendations, the Bulgarian Physical Education and Sport Act, into force since 18.01.2019 (10), defines: Art. 57: (1) Physical activity, Physical Education and sport subject at high education institutions in Bulgaria, is part of bachelor and master education, in the form of compulsory, elective and optional classes, with a minimum workload of 60 compulsory classes per academic year. (2) The system for assessment and evaluation of students' skills in physical activity, Physical Education and sport is determined by each university and in accordance to the Higher Education Act.

In parallel, the Higher Education Act (11), defines and regulates the universities' autonomy. In its previous version was indicated that: "Physical Education and Sport curriculum is developed according to the profile of the university and the proposals of the Students' Council", which gave the universities the freedom of decision on the status of PE and sport subject in their curricula. In 2010, the Higher Education Act changed and defined clearly and eloquently that: „The minimum workload of compulsory sport classes should be 60 classes per academic year, for students acquiring Bachelor degree and for students acquiring a Master degree".

Thus, the AIM of the presented study is to establish the present status and the content of the subject Physical Education and Sport in Bulgarian higher education institutions' curricula.

\section{METHODOLOGY}

1. Pre-study methods - informative studies of literary, documentary and internet sources related to the importance of health enhancing physical activity as well as EU and Bulgarian Government policies in the field.

2. Content analysis of documentary and internet sources related to the subject Physical Education and Sport in the Bulgarian universities' curricula.

3. Theoretical-logical methods: analysis; synthesis; induction; comparison.

\section{RESULTS AND ANALYSIS:}

Table 1 shows up-to-date information about the status of PE and Sport subject in some of the biggest Bulgarian universities' curricula: 
HRISTOVA P., et al.

Table 1. Curricula of the subject Physical Education and Sport in Bulgarian universities.

\begin{tabular}{|c|c|c|c|c|c|c|c|}
\hline \multirow{3}{*}{ № } & \multirow{3}{*}{ University } & \multicolumn{6}{|c|}{ Physical Education and Sport's curricula } \\
\hline & & \multicolumn{3}{|l|}{ Bachelor studies } & \multicolumn{3}{|c|}{ Master studies } \\
\hline & & $\begin{array}{l}\text { C/E/O } \\
\text { subject }\end{array}$ & $\begin{array}{l}\text { Assess } \\
\text { ment }\end{array}$ & $\begin{array}{l}\text { ECTS } \\
\text { credits }\end{array}$ & $\begin{array}{l}\text { C/E/O } \\
\text { subject }\end{array}$ & $\begin{array}{l}\text { Assess } \\
\text { ment }\end{array}$ & $\begin{array}{l}\text { ECTS } \\
\text { credits }\end{array}$ \\
\hline 1. & $\begin{array}{l}\text { University of } \\
\text { National and World } \\
\text { Economy } \\
\text { of Sofia }\end{array}$ & $\begin{array}{l}\text { For all programmes: } \\
\text { - } \text { I year } 1 \text { class per week }=60 \\
\text { compulsory classes } \\
\text { - } \text { II year is elective subject }=60 \\
\text { classes } \\
\text { - } \text { III-IV years not included } \\
\text { - } \text { Theory not included }\end{array}$ & yes & no & $\begin{array}{l}\text { not } \\
\text { included }\end{array}$ & no & no \\
\hline 2. & $\begin{array}{l}\text { Technical University } \\
\text { of Sofia }\end{array}$ & $\begin{array}{l}\text { For all programmes: } \\
\text { - } \text { I-II years } 2 \text { classes per week = } \\
240 \text { compulsory classes } \\
\text { - } \text { III-IV years not included } \\
\text { - } \quad \text { Theory not included }\end{array}$ & no & no & $\begin{array}{l}\text { not } \\
\text { included }\end{array}$ & no & no \\
\hline 3. & $\begin{array}{lr}\text { Dimitar A. } & \text { Tsenov } \\
\text { Academy } & \text { of } \\
\text { Economics } & \\
\text { of Svishtov } & \end{array}$ & $\begin{array}{l}\text { For all programmes: } \\
\text { - } \text { I-II years is elective subject }= \\
120 \text { classes } \\
\text { - } \text { III-IV years is optional subject } \\
\text { - } 8 \text { semester is not included } \\
\text { - } \quad \text { Theory not included }\end{array}$ & no & no & $\begin{array}{l}\text { not } \\
\text { included }\end{array}$ & no & no \\
\hline 4. & $\begin{array}{lr}\text { University } & \text { of } \\
\text { Architecture, } & \text { Civil } \\
\text { engineering } & \text { and } \\
\text { Geodesy } & \\
\text { of Sofia } & \end{array}$ & 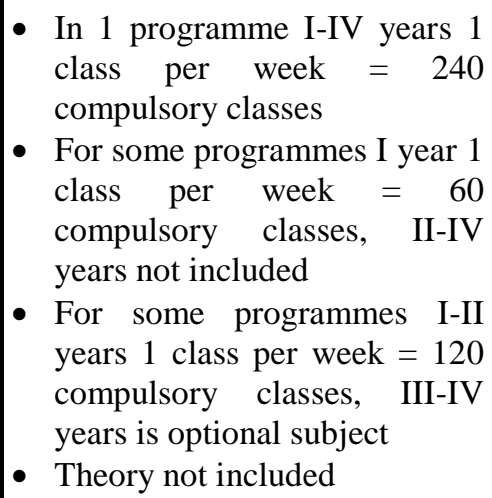 & no & yes & $\begin{array}{l}\text { not } \\
\text { included }\end{array}$ & no & no \\
\hline 5. & $\begin{array}{ll}\text { Angel } & \text { Kanchev } \\
\text { University } & \\
\text { of Ruse } & \end{array}$ & $\begin{array}{l}\text { For all programmes: } \\
\text { I-IV years } 1 \text { class per week } \\
\text { but it is called subject out of } \\
\text { the semester. } \\
\text { - Theory not included }\end{array}$ & no & yes & $\begin{array}{l}\text { not } \\
\text { included }\end{array}$ & no & no \\
\hline 6. & $\begin{array}{l}\text { Technical University } \\
\text { of Varna }\end{array}$ & $\begin{array}{l}\text { For all programmes: } \\
\text { - I-II years } 1 \text { class per week = } \\
120 \text { compulsory classes } \\
\text { - III-IV years not included } \\
\text { - Theory not included }\end{array}$ & no & no & $\begin{array}{l}\text { not } \\
\text { included }\end{array}$ & no & no \\
\hline 7. & $\begin{array}{l}\text { Paisii Hilendarski } \\
\text { University } \\
\text { of Plovdiv }\end{array}$ & $\begin{array}{l}\text { - For some programmes I-II years } \\
1 \text { class per week = } 120 \\
\text { compulsory classes, III-IV years } \\
\text { not included } \\
\text { - For some programmes I year } 1 \\
\text { class per week = } 60 \text { compulsory } \\
\text { classes, II-IV years not included } \\
\text { - For some programmes for all } \\
\text { years is optional subject } \\
\text { - Theory not included }\end{array}$ & no & $\begin{array}{l}\text { only in I } \\
\text { year }\end{array}$ & $\begin{array}{l}\text { not } \\
\text { included }\end{array}$ & no & no \\
\hline
\end{tabular}


HRISTOVA P., et al.

\begin{tabular}{|c|c|c|c|c|c|c|c|}
\hline 8. & $\begin{array}{l}\text { "St. St. Kiril and } \\
\text { Metodii" University } \\
\text { of Veliko Tarnovo }\end{array}$ & $\begin{array}{l}\text { - For some programmes in } \\
\text { different semesters }=30 \text { or } 75 \\
\text { compulsory classes } \\
\text { - For some programmes not } \\
\text { included } \\
\text { - Theory not included }\end{array}$ & yes & yes & $\begin{array}{l}\text { not } \\
\text { included }\end{array}$ & no & no \\
\hline 9. & $\begin{array}{l}\text { "Konstantin } \\
\text { Preslavski" } \\
\text { University } \\
\text { of Shumen }\end{array}$ & $\begin{array}{l}\text { - For some programmes I year } 1 \\
\text { class per week курс = } 60 \\
\text { compulsory classes, II-IV } \\
\text { years not included } \\
\text { - For some programmes for all } \\
\text { years is optional subject } \\
\text { - In } 1 \text { distance learning } \\
\text { programme }=60 \text { compulsory } \\
\text { classes } \\
\text { - Theory not included }\end{array}$ & no & yes & $\begin{array}{l}\text { not } \\
\text { included }\end{array}$ & no & no \\
\hline 10. & $\begin{array}{l}\text { "St. Kliment } \\
\text { Ohridski" University } \\
\text { of Sofia }\end{array}$ & $\begin{array}{l}\text { - For } 1 \text { programme (Low)- I-IV } \\
\text { years } 1 \text { class per week = } 240 \\
\text { compulsory classes; } \\
\text { - For programme International } \\
\text { relations - I-II years } 1 \text { class per } \\
\text { week }=120 \text { compulsory } \\
\text { classes, III year optional } \\
\text { subject }=60 \text { classes, IV year } \\
\text { not included } \\
\text { - For some programmes: I-II } \\
\text { years } 1 \text { class per week }=120 \\
\text { compulsory classes, III-IV } \\
\text { years not included } \\
\text { - For some programmes in } \\
\text { different semesters }=60,120 \\
\text { or } 240 \text { compulsory classes, in } \\
\text { the rest semesters not included } \\
\text { - For some programmes is } \\
\text { elective subject }=30,60 \text { or } \\
180 \text { classes } \\
\text { - For some programmes for all } \\
\text { years is optional subject }=30, \\
60,120 \text { or } 240 \text { classes } \\
\text { - Theory included in } 1 \\
\text { programme only }\end{array}$ & yes & $\begin{array}{l}\text { yes in } \\
\text { few } \\
\text { program } \\
\text { mes }\end{array}$ & $\begin{array}{l}\text { not } \\
\text { included }\end{array}$ & no & no \\
\hline 11. & $\begin{array}{l}\text { University of Mining } \\
\text { and Geology } \\
\text { of Sofia }\end{array}$ & $\begin{array}{l}\text { For all programmes: } \\
\text { - I - II year } 1 \text { class per week }= \\
120 \text { compulsory classes. } \\
\text { - III - IV years is optional subject } \\
\text { - Theory included }\end{array}$ & no & $\begin{array}{l}\text { yes but } \\
\text { out of } \\
\text { the } \\
\text { compuls } \\
\text { ory } \\
\text { credits }\end{array}$ & $\begin{array}{l}\text { not } \\
\text { included }\end{array}$ & no & no \\
\hline 12. & $\begin{array}{l}\text { University } \\
\text { Chemical of } \\
\text { Technology and } \\
\text { Metallurgy } \\
\text { of Sofia }\end{array}$ & $\begin{array}{l}\text { For all programmes: } \\
\text { - In I year } 2 \text { classes per week = } \\
240 \text { compulsory classes } \\
\text { - II - III years } 1 \text { class per week = } \\
240 \text { compulsory classes } \\
\text { - Theory not included }\end{array}$ & no & no & $\begin{array}{l}60 \\
\text { classes } \\
\text { only in } \\
\text { one } \\
\text { program } \\
\text { me }\end{array}$ & no & no \\
\hline 13. & $\begin{array}{l}\text { University } \\
\text { Forestry } \\
\text { of Sofia }\end{array}$ & $\begin{array}{l}\text { For all programmes: } \\
\text { - I - II year } 1 \text { class per week = } \\
120 \text { compulsory classes } \\
\text { - III - IV years is not included } \\
\text { - Theory not included }\end{array}$ & $\begin{array}{l}\text { yes, only } \\
\text { in one } \\
\text { program } \\
\text { me }\end{array}$ & no & \begin{tabular}{|l} 
not \\
included
\end{tabular} & no & no \\
\hline
\end{tabular}


HRISTOVA P., et al.

\begin{tabular}{|c|c|c|c|c|c|c|c|}
\hline 14. & $\begin{array}{l}\text { Medical University } \\
\text { of Sofia }\end{array}$ & $\begin{array}{l}\text { For all programmes and all } \\
\text { years is optional subject }\end{array}$ & no & no & - & no & no \\
\hline 15. & $\begin{array}{l}\text { Free University } \\
\text { of Varna }\end{array}$ & $\begin{array}{l}\text { - For some programmes in I or II } \\
\text { year } 1 \text { class per week }=60 \\
\text { compulsory classes } \\
\text { - II - IV years is optional or } \\
\text { elective subject } \\
\text { - Theory not included }\end{array}$ & yes & yes & $\begin{array}{l}\text { not } \\
\text { included }\end{array}$ & no & no \\
\hline 16. & $\begin{array}{l}\text { Medical University } \\
\text { of Plovdiv }\end{array}$ & $\begin{array}{l}\text { - For some programmes in I year } \\
\text { is optional or elective subject }= \\
60 \text { classes } \\
\text { - For some programmes in I year } \\
1 \text { class per week = } 60 \\
\text { compulsory classes } \\
\text { - II - IV years not included } \\
\text { - Theory not included }\end{array}$ & no & yes & |- & no & да \\
\hline 17. & $\begin{array}{l}\text { Agricultural } \\
\text { University } \\
\text { of Plovdiv }\end{array}$ & $\begin{array}{l}\text { - For some programmes in I year } \\
1 \text { class per week = } 60 \\
\text { compulsory classes } \\
\text { - For some programmes in I year } \\
\text { is elective or optional subject } \\
=60 \text { classes } \\
\text { - For some programmes in I year } \\
\text { is not included } \\
\text { - II - IV years not included } \\
\text { - Theory not included }\end{array}$ & no & no & $\begin{array}{l}\text { not } \\
\text { included }\end{array}$ & no & no \\
\hline 18. & $\begin{array}{l}\text { University of Food } \\
\text { Technologies } \\
\text { of Plovdiv }\end{array}$ & $\begin{array}{l}\text { - For some programmes in I year } 2 \\
\text { classes per week = } 120 \\
\text { compulsory classes; II year is } \\
\text { optional subject; III-IV years not } \\
\text { included } \\
\text { - For one programme in I year } 2 \\
\text { classes per week = } 120 \\
\text { compulsory classes; in II year } 1 \\
\text { class per week = 60 compulsory } \\
\text { classes, III-IV years not included } \\
\text { - For some programmes in I year } 2 \\
\text { classes per week = } 120 \\
\text { compulsory classes; II-IV years } \\
\text { not included } \\
\text { - Theory not included }\end{array}$ & no & yes & $\begin{array}{l}\text { not } \\
\text { included }\end{array}$ & no & no \\
\hline 19. & $\begin{array}{l}\text { Academy of Music, } \\
\text { Dance and Fine Arts } \\
\text { of Plovdiv }\end{array}$ & $\begin{array}{l}\text { For all programmes: } \\
\text { - I - II year } 1 \text { class per week = } \\
120 \text { compulsory classes } \\
\text { - III - IV years is optional } \\
\text { subject } \\
\text { - Theory not included }\end{array}$ & yes & yes & $\begin{array}{l}\text { not } \\
\text { included }\end{array}$ & no & no \\
\hline 20. & $\begin{array}{l}\text { University } \\
\text { Economics } \\
\text { of Varna }\end{array}$ & $\begin{array}{l}\text { For all programmes: } \\
\text { - In I year } 1 \text { class per week = } 60 \\
\text { compulsory classes } \\
\text { - II - IV years not included } \\
\text { - Theory not included }\end{array}$ & no & yes & $\begin{array}{l}\text { not } \\
\text { included }\end{array}$ & no & no \\
\hline 21. & $\begin{array}{l}\text { Medical University } \\
\text { of Varna }\end{array}$ & $\begin{array}{l}\text { For all programmes: } \\
\text { - I - II years } 1 \text { class per week = } \\
120 \text { compulsory classes. } \\
\text { - III - IV years not included } \\
\text { - Theory not included }\end{array}$ & yes & yes & $\begin{array}{l}\text { not } \\
\text { included }\end{array}$ & no & no \\
\hline
\end{tabular}


HRISTOVA P., et al.

\begin{tabular}{|c|c|c|c|c|c|c|c|}
\hline 22. & $\begin{array}{l}\text { Free University } \\
\text { of Burgas }\end{array}$ & $\begin{array}{l}\text { For all programmes: } \\
\text { - not included } \\
\text { - Theory not included }\end{array}$ & no & no & $\begin{array}{l}\text { not } \\
\text { included }\end{array}$ & no & no \\
\hline 23. & $\begin{array}{l}\text { Trakia University } \\
\text { of Stara Zagora }\end{array}$ & $\begin{array}{l}\text { - For some programmes I - II } \\
\text { years } 1 \text { class per week = } 120 \\
\text { compulsory classes; III - IV } \\
\text { years not included } \\
\text { - For some programmes I - II } \\
\text { years } 2 \text { classes per week = } 240 \\
\text { compulsory classes; } \\
\text { III - IV years not included } \\
\text { Theory not included }\end{array}$ & no & no & $\begin{array}{l}\text { not } \\
\text { included }\end{array}$ & no & no \\
\hline
\end{tabular}

Note: $\mathbf{C}$ - Compulsory subject; $\mathbf{E}$ - Elective subject; $\mathbf{O}$ - Optional subject

Of a special importance for the successful fulfilling the tasks of the system of Physical Education and Sport in the higher education institutions, is the problem related to the students' motivation for regular sport activities (12). Some of the possible means (as set in Physical Education and sport Act and in the National Strategy for the development of Physical Education and Sport in the Republic of Bulgaria 2012 - 2022 year) for improving it are:

- Involving students in regular sport classes (at least ones per week) for the full course of the Bachelor and Master studies $(10,11)$;

- Educating the young people on the importance of health enhancing physical activity, the concept of good health, physical hygiene and healthy eating etc. $(13,14)$;

- Including the students' activity and results in the subject Physical Education and sport in the ECTS system (8);

- Introducing full and/or partial scholarships for the most prominent athletes by the higher education institutions (8).

Regardless the Higher Education Act, Physical Education and Sport Act and Ministry of youth and sport's Strategy for the development of Physical Education and Sport in Bulgaria 2012-2020 year (Table 1) the analysis of our study's results show that there is no unified policy towards the subject Physical Education and Sport at the Bulgarian higher education institutions. With one exception, the subject presents in Bachelor studies' programmes, only. Noticeably, even within one university there is difference in the subject's curricula and status in the different programmes. Generally, no one university fulfils the Physical Education and sports Act and the Higher Education Act requirement of 60 compulsory sport classes per academic year for the whole course of studies. In many programmes, the $\mathrm{PE}$ and Sport subject is only elective, optional or not included at all.

The situation is similar regarding the ECTS credits (Table 1). When given, in the most cases, they are not included in the minimum credits required for Bachelor or Master Degree. Moreover, in many cases the students' activities and results in the subject PE and Sport are not evaluated.

Theory as a part of the process of Physical education presents only in the Bachelor's studies in the University of Mining and Geology of Sofia and in one Bachelor programme in "St. Kliment Ohridski" University of Sofia (Table 1).

At present no one Bulgarian higher education institution offers scholarship(s) for prominent athletes.

\section{CONCLUSIONS}

Regretfully, there is a discrepancy between the written on paper Lows, Plans and Strategies for embedding the Physical Education and Sport as a part of overall education of the Bulgarian rising generation and the practice. Bulgarian universities' authorities interpret and apply the Low loosely and selectively and generally do not conduct policy for encouraging young people to exercise. The 
fact that latter is allowed does not show strict State policy on the issue.

\section{RECOMMENDATIONS}

- There should be a clearer definition of the form for applying the minimum curricula of the PE and Sport subject's compulsory classes in art. 57 (1) of the Physical Education and Sport Act's text, by specifying that they should be carried out "in classroom (sport hall)".

- The same clear definition should present and in the Higher Education Act, explaining the options for the implementation of "compulsory and optional PE and Sport's classes with minimum workload of 60 compulsory classes per academic year - as compulsory only; as a combination of compulsory, elective and optional, but never as only elective or optional.

- An effective system and control mechanisms regarding the compliance with art. 57 of the Physical Education and Sport Act to be established by the Government's bodies (for example: the Parliament's Commission for universities' accreditation).

- The theoretical element to become a compulsory part of the Physical Education's process in the higher education as well as a unified system for evaluating students' knowledge (13).

- A unified battery for regular determining and evaluating the students' fitness level to be created and used at all Bulgarian universities.

\section{REFERENCES}

1. www.who.int/ncds/prevention/physicalactivity

2. www.coe.int/en/web/sport/european-sportscharter

3. http://eose.org/wpcontent/uploads/2014/03/resolution_sport_e ducation_2007.pdf

4. https://eur-lex.europa.eu/legalcontent/EN/TXT/?uri=celex\%3A52012IP0 025
5. https://eur-

lex.europa.eu/LexUriServ/LexUriServ.do?u ri=OJ:C:2011:162:0001:0005:EN:PDF

6. https://eur-

lex.europa.eu/LexUriServ/LexUriServ.do?u ri=OJ:C:2010:008E:0097:0105:EN:PDF

7. www.euro.who.int/en/health-topics/diseaseprevention/physical-activity/activities/hepaeurope

8. http://mpes.government.bg/Documents/Doc uments/Strategii/Strategia_2012-2022.pdf

9. Peltekova, I, Monitoring of the physical activity in the young generation's daily life. The pedagogical environment at the university as a space for professionalpersonal development of future specialists, ISBN 978-954-490-161-5, EKS-PRESS Publishing, pp. 555-557, Gabrovo 2010.

10.http://mpes.government.bg/Documents/Doc uments/Zakoni/2019/ZAKON_za_fizicesko to_vyzpitanie_i_sporta_13_08_2019.pdf

11.Higher Education Act (in force since 25.02.2020).

12.Tumanova, B, Studying the motivation for physical activity during spare time and in sport classes of university students who have never exercised. The pedagogical environment at the university as a space for professional-personal development of future specialists, EKS-PRESS Publishing, Book 2, ISBN: 978-954-490-510-1, pp. 423-427, Gabrovo 2016.

13.Peltekova, I, Comparative analysis of Physical Education and Sports programs at universities in Bulgaria and China. The modern teacher's competence, Book 2, Editors Tamara Zacharuk, Aneta Niewęgłowska, ISBN 978-83-934036-9-1, Siedlce Publishing, pp. 146-151, Poland 2012.

14.Ivanov, J. The theoretical component in the process of Physical Education at the universities, Dissertation, Sofia 2006. 